\title{
全国幹線旅客純流動の調查与法の研究 ${ }^{*}$
}

The Methodology of Nationwide Intercity Person Trip Survey

$$
\text { 伊東 誠 }{ }^{* *}
$$

1 . 研究目的

都市圈内の交通に関しては、旅客はＰT調査によりトリップ目的・起終点・個人属性が調査され、貨物は物流調查によ り品目別の動き・荷主の属性などが調査されており、詳細な資料が得られている。全国都市間交通に関しては、貨物は都 市圈と同様な品目別の調査が行われているのに対し、旅客は旅行目的別の調査データがなく旅行の真の発着地や旅行者の 属性も把握できていない。幹線交通機関利用者を的確に予測し、きめ細かな交通政策の導入効果を検討するためには、以 下の項目を調査する全国幹線旅客純流動調査を実施し、これら項

目の相互の関係を分析することが必要である。

・旅行の真の発着地間の流動(純流動と呼ぶ)

- 旅行目的

- 利用交通機関

・旅行者の社会経済属性

・アクセスイグレス交通機関

・交通機関のサービス水準

本論文は上記全国調査の調査方法の検討、具体的には表- 1 k示 す予備調査を実施し次の諸点に関する検討を行なうことを目的と する。

(1)既存旅客統計調査を検討し、問題点を抽出すること。

(2)調查設計の上で全国幹線旅客純流動調査固有の難しい点であ る、調査手法、調査対象期間、調査項目に関する検討を行うこ と。

(3)予備調查結果を用いて、旅行目的別旅行回数、目的地の選択 性向、交通機関の選択メカニズムなどの分析を行い、全国幹線 旅客純流動調査が全国幹線計画にどの様に役立つかを明らかに すること。

2 . 既存旅客統計調查の検討

我国で実施されている数多くの旅客輸送・旅行に関する統計調 査の中から、起終点が調査対象に含まれており、かつ広範な地域 を対象としているものを主として選び、調査対象・内容・方法等 の検討を行った。検討対象とした統計調査の概要を表一 2 に示す 。検討の結果、表ー3に示す様に、既存統計調査には上記観点を 満たすものはないことが判明した。

3 . 調査対象旅行の設定

全国調查を実施する場合、いかに日常的な交通を排除するか が大きな問題となる。日常的な交通の排除を試みる際に、同時 に幹線交通計画の対象とするトリップを落す危険があり、そこ に全国幹線旅客調査の普しさがある。ここでは調査対象とする 幹線旅客を『幹線交通機関・施設を利用して行う旅行もしくは 利用可能性のある旅行』と定義した。幹線交通機関・施設とは 、以下に示す、主として日常生活圈間の交通サービスを提供す るものである。(1)航空機(2)新幹線(3)在来線特急列車(4)在来線急 行列車(5)高速道路（都市内高速道路を除く）(6)長距部旅客船 エリー。従って、『現在利用している旅行』については対象が 明確であるが、『利用可能性のある旅行』に関してはての対象 が曖昧である。後者、即ち幹線交通機関にとっての潜在需要も

\begin{tabular}{|c|c|}
\hline 調查対象地区 & 東京郬、石川慁（能登を除く） \\
\hline 鼓查对象旅行 & 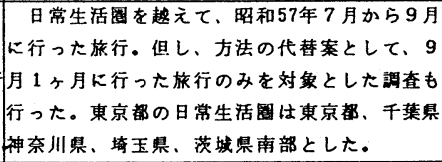 \\
\hline 調査实施期間 & 昭和57年9月下旬 10月上旬 \\
\hline 畦查方法 & 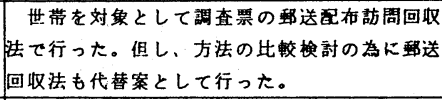 \\
\hline 抽出方法 & 多段ランダムサンプリング法 \\
\hline サンプル 数 & 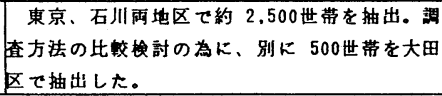 \\
\hline
\end{tabular}

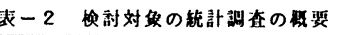

\begin{tabular}{|c|c|c|c|c|}
\hline 䊩 & 統計調查名 & 触查機関 & 辣查年 & 酗查力法ほか \\
\hline 1 & 旅客地域流動调查 & 遇㢵省 & 每 年 & $\begin{array}{l}\text { 鬲送機関別統計を } \\
\text { 含成した二次統計 }\end{array}$ \\
\hline 2 & 道路交通センサス & 建設省 & $\begin{array}{l}3 \text { 年に } 1 \text { 回 } \\
\text { 最近は58年 }\end{array}$ & 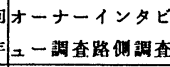 \\
\hline 3 & 全国旅行县㙰訊査 & 短理府 & $\begin{array}{l}\text { 圆和 } 364247 \\
5256 \text { 年 }\end{array}$ & $\begin{array}{l}\text { 可世帯を対象とした } \\
\text { 㕫間調查 }\end{array}$ \\
\hline 4 & 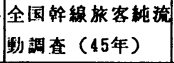 & 運陯省 & 眧和 45年 & $\begin{array}{l}\text { 交通機関利用者に } \\
\text { 对するアンケート }\end{array}$ \\
\hline 5 & 中央道の影敏部查 & 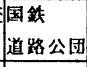 & $\begin{array}{l}\text { 积和54年 } \\
\text { 委等每 }\end{array}$ & $\prime \prime$ \\
\hline 6 & 航空旅客黟態甿奋 & 韪饸省 & $\begin{array}{l}2 \text { 年に } 1 \text { 回 } \\
\text { 最近は56年 }\end{array}$ & 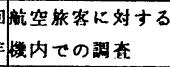 \\
\hline 7 & 钼光の実態と意向 & $\begin{array}{l}\text { 日本䚋光 } \\
\text { 㙝会 }\end{array}$ & 2 年に 1 成 & 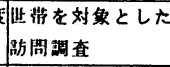 \\
\hline 8 & $\begin{array}{l}\text { 大都市住民の睌珖 } \\
\text { レクリェーシ }\end{array}$ & $\begin{array}{l}\text { 日本観光 } \\
\text { 弨会 }\end{array}$ & $\begin{array}{l}\text { 任ぼ } 2 \text { 年に } \\
1 \text { 度 }\end{array}$ & $" \prime$ \\
\hline
\end{tabular}

跋一 4 奶似とする旅行の定斿

\begin{tabular}{|c|c|c|}
\hline 㥂 点 & 笵 & ポ 1 ข \\
\hline 1 旅行唯部 & 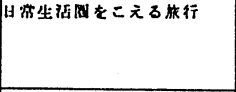 & 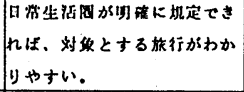 \\
\hline 2 旅行荗组 & 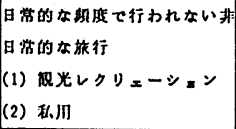 & 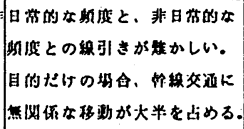 \\
\hline & 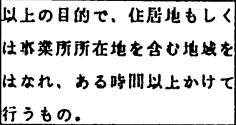 & 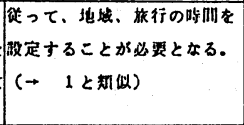 \\
\hline
\end{tabular}

* 幹線、旅客純流動、調奋方法

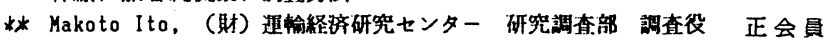


あわせて把握する為には、幹線旅行を別の観 点から捉えることが必要である。そこで、幹 線旅行を次の 3 つの特性により特定する。

(1) 旅行距旅 (2)旅行度 (3)旅行目的 各特性からみた、対象とする旅行の範囲お よび対象旅行設定の際のポイントを表ー4に 示す。本研究では対象とする旅行が明確に规 定できる旅行距離により、調査対象とする幹 線旅行を設定した。具体的には、全国を日常 生活圈に区分し、各生活圈域を越えて行う旅 行を幹線旅行とした。

4. 調査方法代替案の比較検討

\section{(1) 検討の視点}

調査対象旅行は、通勤通学目的卜リップの 梾に生活圈内の日常的なものではなく生活圈 域を越えて行う非日常的旅行である。

その為全国調査の実施方法の確立には、以 下に示す本調査固有の難しさを、解決するこ とが必要である。そこで、予備調査に於てい つかの調査方法代替案を設定し、調查方法の

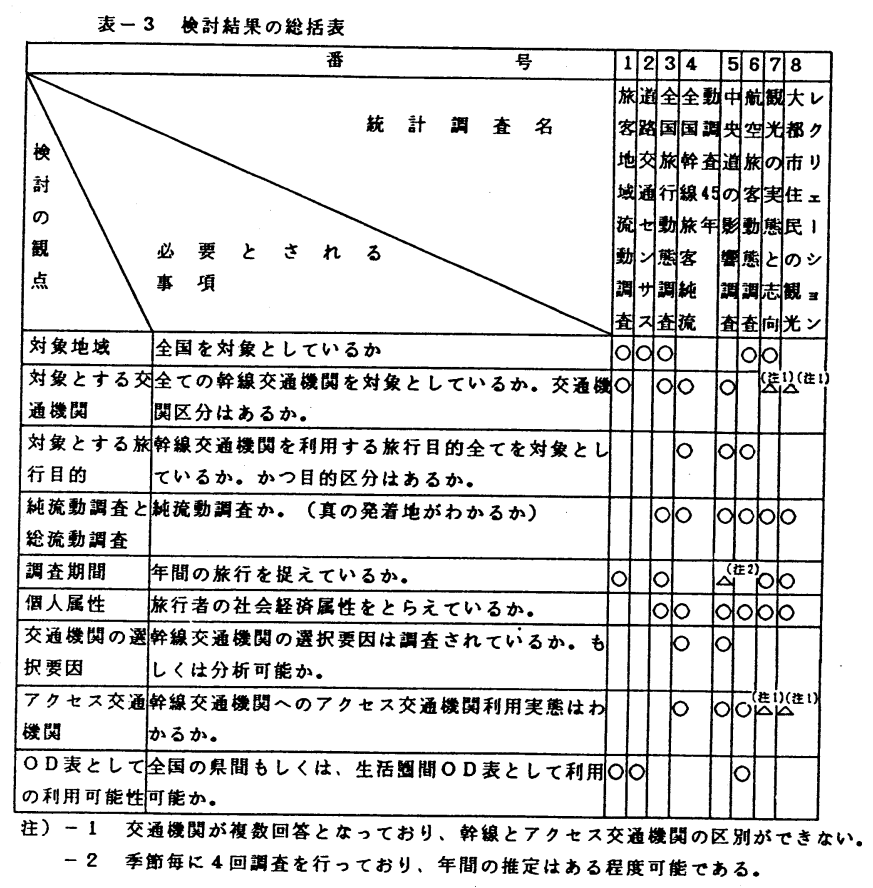
の比較検討を行った。

（イ）調查対象の問題（世帯調㚗と利用客調㚗）

全国調㚗の調査対象としては、居住地べースの個人・世帯と、幹線交通機関利用客とが考えられる。各調査対象による 調査方法の比較検討結果を表- 5 に示す。既存の調査には幹線旅行に関する情報を奻率的に得ようとして、幹線交通機関 利用客を調查対象とするものが多い。しかし、これには(1)幹線交通機関を現在利用しているもの、および利用可能性のあ るものの両者を把旺する必要があるが、利用客調査では、後者が把握できない。(2)年間量を把提するために拉大が必要と なるが、交通機関利用客では母集団が把㩧できないという問題点がある。以上検討の結果、調㚗対象は、個人・世帯が望 ましいとの結論を得た。

（ロ）調査手法の問題

全国調査は極めて大規模な調査であり、調査コ スト削堿も大きな課題である。居住地べースの個 人・世帯を対象に調査を実施する場合、調査手法 として次のものが考えられる。

(1) 郵送配布諥送回收法 (2)諥送配布訪問回收法。 (3)訪問配布訪問回收法。

調査対象トリップ、調査対象期間、払大方法等 を検討の結果、限られた調査費用の中で有効標本 数が多く得られ、かつ調査内容が正確である(2)の 手法が妥当であるとの結論を得て予備調査ではこ の手法を採用した。この調査手法の最大の欠点で ある調査員を多く必要とすることへの対策として

郵送配布諥送回収法を代替手法として設定し、 比較検討することとした。

（ハ）調査項目の問題

幹線交通政策検討のためには、旅行内容・個人

\begin{tabular}{|c|c|c|}
\hline & 居住地ベースで世帯・個人を詿亘単位 & 交通機関ベースて利用客を胠査単位 \\
\hline $\begin{array}{l}\text { 触盁対要 } \\
ト 1 \ldots, 7^{\circ}\end{array}$ & $\begin{array}{l}\text { - 世带もしくは個人の行った旅行 } \\
\text { ・対象旅行は通宜設定可能 }\end{array}$ & $\begin{array}{l}\text { - 交通機闌、施設利用客が行ってい } \\
\text { 万旅行. }\end{array}$ \\
\hline $\begin{array}{l}\text { 晐亘対象 } \\
\text { 期間 }\end{array}$ & ・設定は自由にてきるる。 & $\begin{array}{l}\text { ・特定の日に幛㚗することになり， } \\
\text { 䚴㚗日もサンブリング対象となる。 }\end{array}$ \\
\hline $\begin{array}{c}\text { 母集団 } \\
\text { と } \\
\text { 抽出方法 }\end{array}$ & 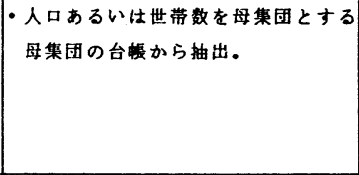 & 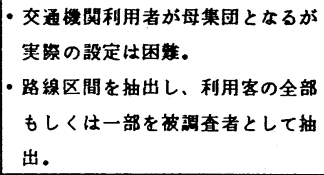 \\
\hline 扭大力法 & - 抽出方法による。 & 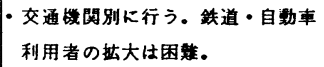 \\
\hline $\begin{array}{l}\text { サンプル } \\
\text { の } \\
\text { 特 铔 }\end{array}$ & 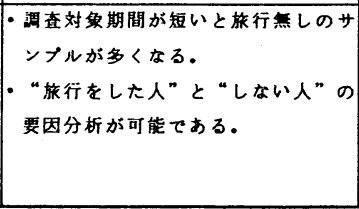 & 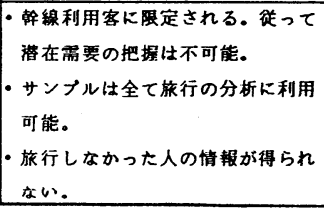 \\
\hline
\end{tabular}


属性に関する多くの情報を収集することが望ましい。しかし調㚗 項目が多い場合、(1)郵送配布でもあり、十分な回答をミスなく得 られるか。(2)逆上って3ヶ月間の旅行を調査することとしている が、被調查者にとり負担が大きくなり回答拒否やある旅行を意識 的に選択して記入する等の問題が発生することが考えられる。そ こで調查項目としては表一6の本方式の㯗に示すものを基本とし 、簡略化した代替案との比較検討を行った。

\section{(二) 調查対象期間の問題}

調査対象とする旅行は、実態調査時点から逆上って数ヶ月間に 行った旅行となる。非日常的な旅行の頻度はさほど多くないため 調査で多くのトリップ情報を得るためには、対象とする期間を長 くすることが必要である。季節変動があるため、できれば 1 年間 を調査対象期間とすることが望ましい。しかし、調査対象期間を 長くすると、回答拒否や、数多い旅行のなかから意証的にある旅 行を選択する等の問題が発生する恐れがある。既存の旅行統計調 㚗から 1 人当り旅行回数を推定した結果、過去 3 ヶ月に行った旅 行を調查対象とし（年間流動を把握するためには年 4 回の調査が 必要となる）、過去 1 ヶ月を調査対象とした代替案との比較梌討 を行った。

以上の检討の組合せとして設定した調査方法の代替案を表ー 7 に 示す。

\section{（2）調査方法代替案の比較検討結果}

(1) 調查手法

郵送配布郵送回収には、次の問題点があることが判明した。

（イ）方式 4 の旅行経煥率は76\%と、本方式、方式 2 に比べ際立 つて大きい（表一8）。これは旅行経験者が未経験者より、回答 に対し皘極的な傾向を示すことによる。何らかの改善策を講じた としてもこの偏りの是正は困難と思われる。郵送回収法によるこ の調査結果を用い母集団推定を行うと、推定結果に歪を生じるこ ととなる。

（ロ）郵送回収法で行った場合、回答者の職業構成にも偏りが生 じる。図ー1 は男性回答者の職業構成をみたものでる。方式 4 は他の手法に比べ管理職の構成が大きい。

（八）調査項目の記入状況は良好であった。方式による記入状況 の差異を正答率（被調査者が正しく回答した率）により比較した 結果、方式 4 の正答率は約90\%であり方式 2，3 とほぼ等しく、 本方式を上回り、今回の予備調査に限れば、郵送眍布でも調査主 旨は徹底できた梾にみえる。しかし、郵送回収法には回答者の偏 りがあり、また全国調査では調査項目が多いことを考えると、全 国調査の手法としては適当でないと思われる。

以上検討の結果、調査手法は郵送配布訪問回收法が望ましい手法であると考える。 (2)調査項目

調査票を簡略化した方式 2 との比較㛟討を行った結果、明かになった点は以下のとうりである。

（イ）調査項目が多い場合、回答拒否が增元、回収率が低くなることが危惧された。しかし、表一 9 に示す様に、本方式 、方式 2 ともに回収率は69\%であり、差異はみられなかった。

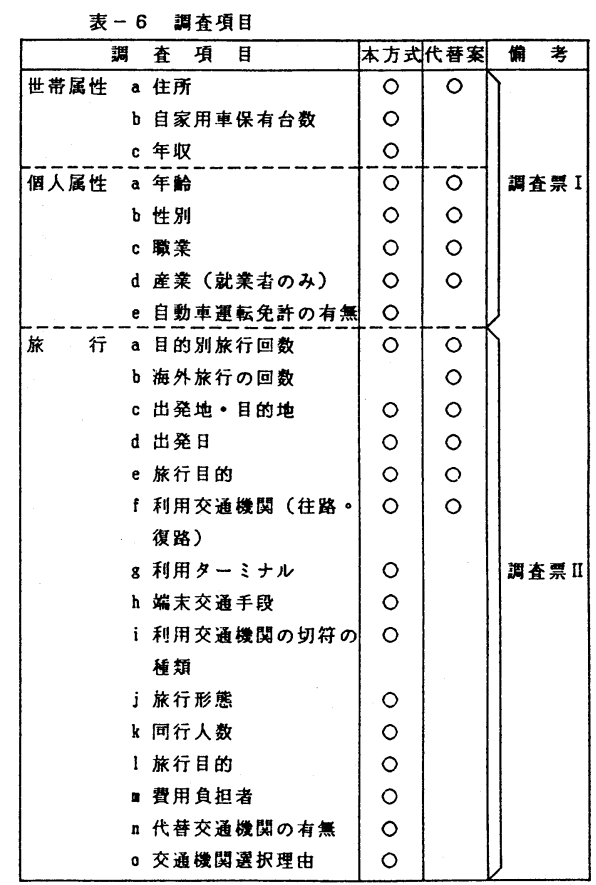

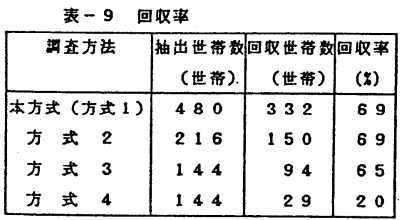

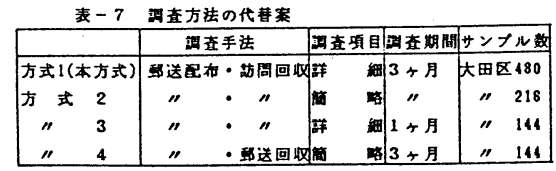

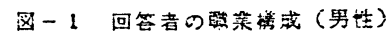

\begin{tabular}{|c|c|c|c|c|}
\hline & 部菜者 & 它理 & 字生 & s \\
\hline 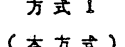 & $53:$ & i $1:$ : & $30 \%$ & \\
\hline 方式 2 & 47 & 12 & 33 & 8 \\
\hline 方式 3 & 55 & 3 & 29 & 8 \\
\hline 方式 4 & 40 & 29 & 31 & \\
\hline
\end{tabular}

\begin{tabular}{|c|c|}
\hline 表一 & 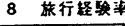 \\
\hline 和坴方证 & 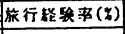 \\
\hline 太方式 & 41 \\
\hline 方式 2 & 43 \\
\hline 方式 3 & 12 \\
\hline 方式 4 & 76 \\
\hline
\end{tabular}

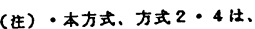
57年 7、8、9月の矢行 经酸事 ・方式 3 は、57年 9 月の获 行䄳铁事 
（ロ）調査項目が多い場合、記入を億劫がり“旅行なし”とする被調査者の增加が臨念された。本方式による旅行経䜽率 は41\%、方式 2 は3\%\%で、ほとんど美異はみられなかった。また本方式と方式 2 にる 1 人当り旅行回数（表－10）の 平均值の差を全目的、旅行目的別に検定した結果、その他目的旅行を除き有意な差はみられない。（その他目的は $5 \%$ の危険率で有意となったが、本方式の方が回数が多く、別な要因によるものと思われる。）

（八）調査項目が多い場合、記入ミス、記入漏れが多くなり、調査効率が悪化することが䜿念された。本方式と方式 2 の 記入状況を正答率で比較した結果（表-12）、本方式は84\%、方式 2 は89\%であり、簡略化した項目のみをみても85\%と

、調查項目が増すと被調査者の記入ミス、記入漏れがやや増加する傾向がみられる。

（二）本方式の調査項目での調査は（イ）（ハ）により、調査票の回収労力が大きく、全国胭㚗実施の然の手法として 不適であることが危惧された。回収労力を表わす指標として、一票を回収するのに要した訪問回数をとり比较した結果、

いずれも 2.3回であり差はみられない（表－13）。

以上検討の結果、調査項目の増加は記入状珿をやや悪くするが、この点については調査票の改善、調査員への指示の徹 底などで十分対応でき、全国調査の調査項目は本方式のものが可能であり望ましいとの結詥をえた。

(3)調査対象期間

調査対象とする旅行は被調査者が調㚗時点から遏去 3 ヶ月に行っ た旅行としている。しかし、過去 3 ヶ月の場合、旅行数が多すぎて 記入できない被調査者が多く出現し、胭査結果に歪みを生じる危険 がある。そこで、対象期間を過去 1 ヶ月とした方式 3 との比較検討 の結果は以下のとうりである。

（1）本方式および方式 2 による通去 3 ヶ月間の 1 人当り平均旅行 回数は 0.7 回であり、この意味では全く問題はない。1 1 人当り旅行 回数の分布をみても、観光レクリェーション、その他目的旅行は 4 回以下のものが殆どである。業務目的で10回以上旅行を行っている ものがある。しかし、これらは業務目的旅行者の 4 \% 程度である こと、また、回数の多い人は同一目的地同一交通機関利用の旅行が 多いため記憶をたどるのが比較的容易であることから、3ヶ月調査 で十分に調査できると考える。

（ロ）逆に対象期間を 1 ヶ月とすると、“旅行未経験者”が多くな り、調査効率が悪くなる。又“旅行なし”の者は、“旅行あり”の 者に比べて回答を拒否する傾向がみられ、方式 3 の回収率は65\%と 本方式、方式 2 の $69 \%$ に比べて低くなっている。

以上検討の結果、調査期間は 3 ヶ月が妥当であると考える。

本方式と代替案方式の比較検討を行った結果、本方式が望ましい 調查方法であり、この方法による全国調査は十分に可能であるとの 結論を得た。

5 . 旅行特性の分析

予備調査の主たる目的の一つは、この種の調査で、どの様な分析 方法により、どの様な結果が得られるかを、全国調㚗に先立って把 握しておくことにある。予備調査の解析結果のうち、主として幹線 旅客純流動調査の実施により明かになる旅行特性を以下に述べる。 $5-1$ 旅行経験率

調査対象期間である昭和57年 7 月〜 9月の旅行経験率は東京・石 川両地区とも42\%であり差が無い。 旅行経耠率の地域差を 知ることは全国調査の大きな目的の 1 つである。

5-2 旅行目的别旅行回数

(1) 旅行目的構成
表一 10 旅行目的别 1 人当り旅行回数

(単位：回）

\begin{tabular}{|c|c|c|c|c|}
\hline & \multicolumn{4}{|c|}{ 1人当旅行回数 } \\
\hline & 䈔 光 & 務 & 私 用 & 誄 \\
\hline 本方式（方式 1) & 0.360 & 0.086 & 0.280 & 0.705 \\
\hline 方 式 2 & 0.443 & 0.115 & 0.203 & 0.760 \\
\hline 方 式 & 0.058 & 0.025 & 0.062 & 0.145 \\
\hline 方 式 & $0.77 ?$ & 0.375 & 0.417 & 1.569 \\
\hline
\end{tabular}

(注) 方式 $1 、 2 、 4$ は $7 、 8 、 9$ 月の旅行 方式 3 は9 月の旅行

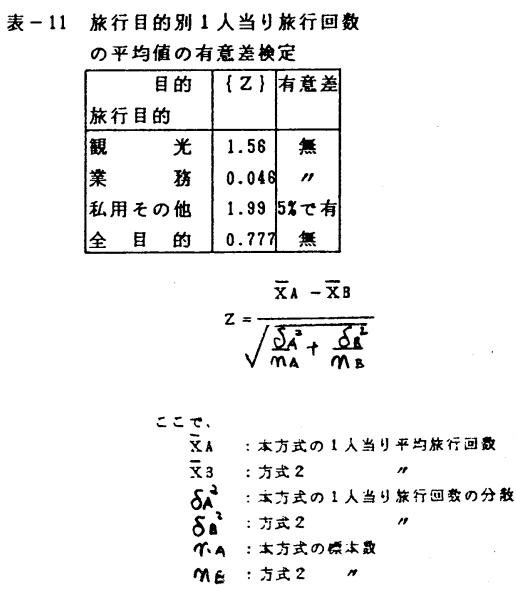

表ー13 1 票回収する為の

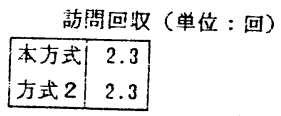


旅行目的により旅行特性は大きく異なる。従って全 国幹線交通計画立案の基礎資料には、旅行目的別に捉 えたものが、是非とも必要である。図-2に旅行目的 別旅行数および目的構成を示す。旅行の約 $50 \%$ が観光 レクリェーション目的で、30\%が㴆省・私用等のその 他目的、残りが業務目的である。但し、予備調査は 7 $\sim 9$ 月の旅行を対象としているため、年間に比べ、観 光レクリェーション旅行の構成比が大きくなっているものと 思われる。幹線旅客は季節变動が大きいため、年間を通して して調査することが必要である。

（2） 1 人当りの旅行回数

全目的で東京 0.72 回/人、石川 0.94 回/人である。旅行目 的により回数に差がある。男女別に回数を比較すると業務目 的旅行の多い男性が女性を上回っている。

(3) 旅行回数別人数分布

図一 3 は東京地区に於る旅行回数別人数分布をみたものて ある。全目的では、旅行回数 4 回迄の者が多く、それ以上は 少ない。これを目的別にみると、観光レクリェーション目的 、その他の目的は旅行回数の少ない者が多いのに対し、業務 目的は旅行回数 4 回以上も $20 \%$ 程度あり、10回以上も $4 \%$ 強ある。業務目的は旅行経験率が低いことも併せ考えると、 特定の人間が数多くの旅行を行う傾向にあるといえる。 $5-3$ 旅行目的地別旅行数

東京地区に於る旅行数の多い旅行目的地（都道府県）を表 - 16 に示す。静岡、山梨、長野、大阪、茨城への旅行が多 いが、旅行目的により分布パターンが異なる。旅行目的別旅 行数に季節変動があるため、年間を通じた旅行目的別分布交 通量の把握が是非とも必要である。

5-4 主な利用交通機関

主な利用交通機関（出発地から目的地迄に利用した交通機 関のうち、最も長い距離を利用したもの）の分担率は、図一 4 に示す様に、旅行目的により大きく異なる。これは、主と して次の 2 点によるものと思われる。1旅行目的別に交通機 関選択要因が異なる。(2)目的地迄の交通機関のサービス水準 が異なる。図-5 は、東京 $\rightarrow$ 静岡県間の交通機関分担率を旅 行目的別に比較したものである。明らかに旅行目的により選 択性向が異なっている。図一6 は交通機関のサービス水準が 異なる区間に於ける、観光レクリェーション目的旅行の交通 機関分担率を比較したものである。同一目的の旅行であって も区間により交通機関分担率が大きな差がある。季節により 旅行目的が異なり、目的地が变化することも併せ考えると、 非日常的な幹線交通を検討する基礎資料としてお、年間の特 定の日の交通を対象としている道路交通センサス、航空旅客 動態調査等の調査では十分とはいえず、年間流動を捉えてい るとされている旅客地域流動調査でも、航空以外は特定の月

表-14 回收率と满查不能理由

(世葷 : \%)

\begin{tabular}{|c|c|c|c|c|c|c|c|c|}
\hline \multirow{2}{*}{$\begin{array}{l}\text { 抽出事 } \\
\text { (世常) }\end{array}$} & \multirow{2}{*}{$\begin{array}{l}\text { 回収数 } \\
\text { (世带) }\end{array}$} & \multirow{2}{*}{$\begin{array}{c}\text { 回収莿 } \\
(\%)\end{array}$} & \multicolumn{6}{|c|}{ 調 查 不能理 由 } \\
\hline & & & 合計 & 拒否 & 不在 & 硋当繁し & 転出 & その他 \\
\hline \multirow[t]{2}{*}{2047} & 1356 & 66.2 & 691 & 174 & 309 & 32 & 130 & 46 \\
\hline & & & $(100.0)$ & $(25.2)$ & $(44.7)$ & (4.6) & $(18.8)$ & $(6.7)$ \\
\hline \multirow[t]{2}{*}{507} & 372 & 73.4 & 135 & 59 & 41 & 21 & 9 & 5 \\
\hline & & & $(100.0)$ & $(43.7)$ & $(30.4)$ & $(15.8)$ & $(6.7)$ & (3.7) \\
\hline
\end{tabular}

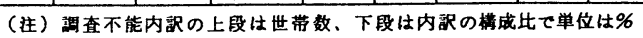

因-2 旅行の日的满战

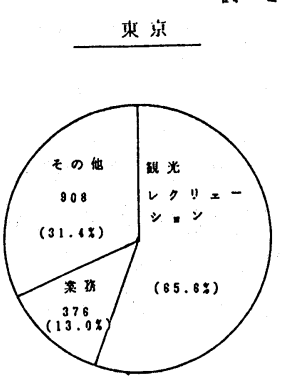

们川

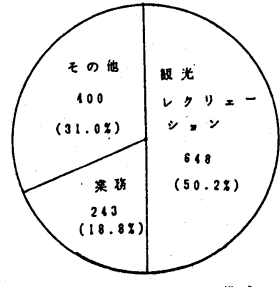

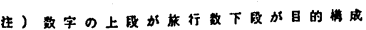

\begin{tabular}{|c|c|c|c|c|c|c|c|c|}
\hline \multirow{3}{*}{\multicolumn{3}{|c|}{$\underbrace{\text { 表 }-15 \text { 人当りの }}_{\text {旅行目的 }}$}} & & & \multicolumn{4}{|c|}{ （単位：回／人 } \\
\hline & & & \multicolumn{2}{|c|}{ 東 } & w & \multicolumn{2}{|c|}{ 石 } & गII \\
\hline & & & 男 & 女 & 計 & 男 & 女 & st \\
\hline \multicolumn{3}{|c|}{ 観光レク } & 0.43 & A. & .40 & 0.49 & 0.45 & 0. \\
\hline 藻 & & 敛 & 0.17 & & .09 & 0.34 & 0.03 & 0.1 \\
\hline$z$ & & 他 & 0.25 & & .23 & 0.28 & 0.30 & 0.2 \\
\hline 全 & & 的 & 0.85 & & .72 & 1.11 & 0.77 & 0.9 \\
\hline
\end{tabular}

\begin{tabular}{|c|c|c|c|c|c|c|c|c|c|}
\hline & -18 & 旅行目 & 的地别 & 的行回 & & \multicolumn{2}{|c|}{ 東京） } & \multicolumn{2}{|c|}{ （単安：回） } \\
\hline \multirow[t]{2}{*}{ 酥 文 } & \multicolumn{2}{|l|}{ 鼠光 } & 莱 & 弱 & \multirow{2}{*}{$\frac{z}{z}$} & の & 他 & 全 & 的 \\
\hline & 禁 & 旅行数 & 名 & 症行数 & & 名林 & 行数 & 年 & 旅行数 \\
\hline 1 & 䑩 阙 & 517 & 岡 & 52 & 山 & 媇 & 84 & H & 847 \\
\hline 2 & $\mid \begin{array}{ll}\mid E_{1} & \text { 䟥 }\end{array}$ & 213 & 大 & 50 & 港 & 蛲 & 81 & E & 306 \\
\hline 3 & 山列 & 158 & 福 & 30 & 長 & P? & 79 & 山 & 251 \\
\hline 4 & 木 & 147 & 斩 & 21 & A & 岡 & 78 & 质 & 212 \\
\hline 5 & 馬 & 92 & 受 & 21 & 福 & 島 & 59 & 揊 & 158 \\
\hline 6 & 离 & 69 & 荻 & 19 & 新 & 渴 & 58 & 荻 & 145 \\
\hline 7 & 北海道 & 46 & 京 & 17 & $\mid \frac{1}{5}$ & 木 & 44 & 群 & 144 \\
\hline 8 & 新 晹 & 48 & 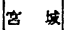 & 16 & 群 & 馬 & 33 & 新 & 113 \\
\hline 9 & 故 & 45 & 北海通 & 14 & 北海 & & 32 & 北海道 & 92 \\
\hline 10 & 京 & 30 & E & 16 & 宫 & 城 & 28 & 大 & 78 \\
\hline 全目的 & & 1607 & & 378 & & & 908 & & 2991 \\
\hline
\end{tabular}

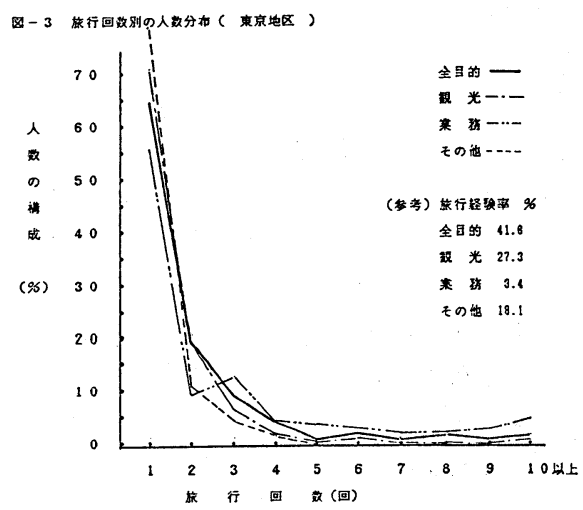


の流動パターンで年間流動を推計しているため、実際の年 間流動との間にかい教が生じている可能性が大きい。以上 の点からも全国幹線旅客純流動調査の実施が必要であるこ とが強調される。

\section{5 - 5 アクセス交通機関}

高速交通機関の整備に伴いアクセス交通機関の重要性は 一層大きくなっており、幹線交通機関のターミナルおよび そこに至るアクセス交通機関の利用実態把握は、今後の幹 線交通政策にとり極めて重要である

(1) 利用ターミナル構成

図-7は東京地区の、新幹線、在来線特急急行利用者の 利用ターミナル構成を見たものである。新幹線は東京剾利 用が $80 \%$ 以上を占め大宮利用は $15 \%$ 程度となっている。在 来線特急急行は上野殹利用が50\%を上回り次いで新宿、東 京駅の順となっている。

\section{（2）アクセス交通機関}

図一8 は東京地区の航空機（羽田空港のみ）、新幹線、 在来線特急急行利用者のアクセス交通機関 (交通機開) 構 成比をみたものである。新幹線、在来線特急急行利用者は アクセス交通機関に普通電車を利用する者が圧倒的に大く

、航空機利用の場合はタクシー利用も多い。

以上の様に従来の調㚗では十分に把握できなかったアク セス交通実態が、全国幹線旅客純流動調㚗の実施により把 暒できることが明らかとなり、本調㚗がこの点からも十分 意義のあることが確㑇できた。

\section{5-6 個人の社会経済属性と旅行特性}

調査結果を分析した結果、㑑人の社会経济属性が旅行特 性に大きな影籍を及ぼすことが半明した。以下、主要な属 性と旅行特性の関係を述べる。

\section{（1）乗用車保有の旅行に及ぼす影響}

表一 17 は被調査者を乗用車保有世帯と非保有世帯に構 成員を区分し、1 1 人当り旅行回数の比较を行ったものであ る。保有世帯は非保有世帯を上回る旅行を行っており、そ の差は観光レクリェーション目的により生じていることが 明らかとなった。次に東京地区に於る観光レクリェーショ ン目的旅行の目的地別旅行数を保有・非保有世带別に比较 したところ、乗用車保有世帯は東海、甲信、北関東等近互 離の地域で非保有世帯を大きく上回り、乗用車の保有は目的 地選択にも大きな影䇾を及ぼしていることが明らかとなった （表－18）。図-9は東京地区の主な交通機関分担率を保有 ・非保有世帯別に比较したものでる。非保有世帯では特急 急行列車、新幹線利用が多く、保有世帯では乗用車利用が多 いことがわかる。

\section{(2) 職業別の業務目的旅行}

図-10は、東京地区の職業別 1 人当り業務目的旅行回数を
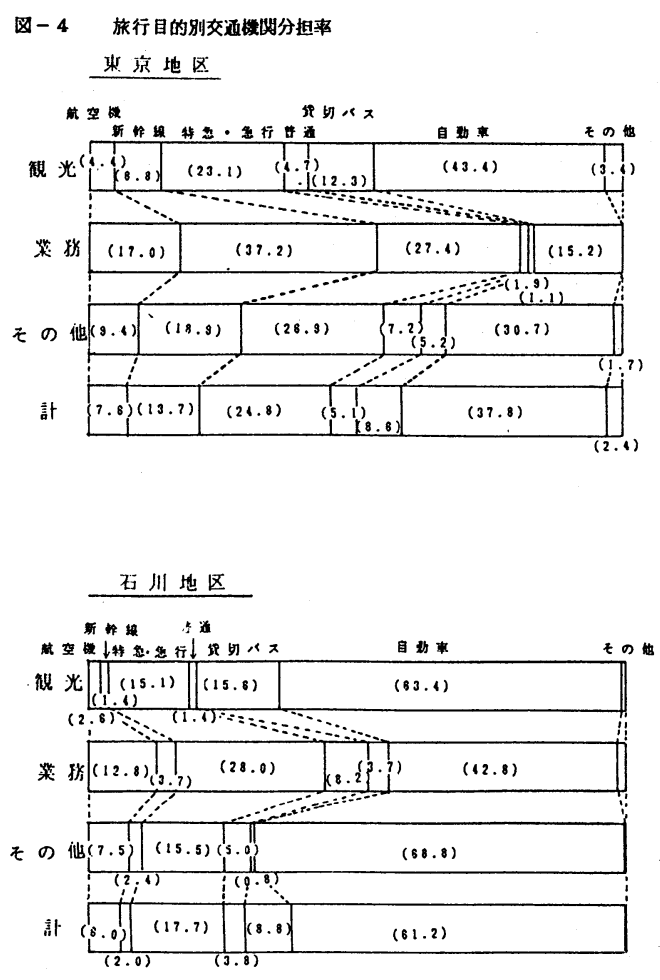

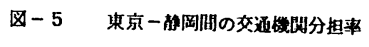
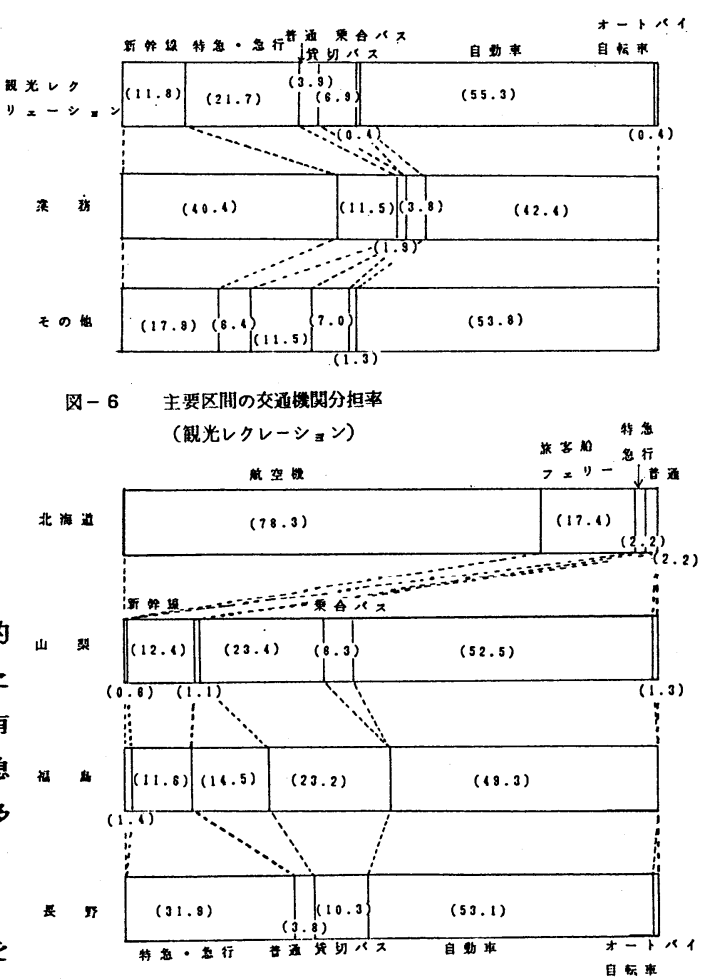
表わしたものである。職業により回数に差があり、管理的㙂亲 従業者、専門的技術職業従羓者、暊売従業者は旅行回数が多い 以上検討の結果、”旅行特性は㑑人の社会経済属性により大き な影響受けるため、この観点から行われる全国幹線旅客純流怔 調查は、全国幹線交通計画立案にとり非常に有意義であること が明らかとなった。

\section{6 . 非集計モデル適用の可能性}

今後の幹線交通政策は従来にも增して、一層き細かな施策 が必要となることが予想される。予測手法としては、以下に述 バる理由により非集計データによる分析および予測モデルの構 筑が必要であると考える。

(1) 集計データによる分析には細かいゾーン間での旅行目的別 O D表を作成することが必要であり、これには脚大なデータが 必要である。

(2)きめ細かな政策検討には、個人の行動原理にもとずく分析 予惻モデル構筑が必要である

(3)アクセス交通機関の分析には、発地が特定でき、かつ幹線 のターミナル迄のアクセス交通機関の利用状況が把提されてい るこが必要であり、その為には非集計データによることが必要 である。

本調査結果を用いることにより、この観点からの分析および モデル構筑が可能である。胭査結果を用い非集計交通機関選択 モデルの構筑を試みた。対象とした旅行は、東京地区の観光レ クリェーション目的旅行て、選択の単位として、(1)㑑人が選択 *

(2) 世帯で選択の 2 単位を考えパラメータ推定を行った。個人 モデルの推定結果を表ー19に示す。運 貨、時間の他、運行頻度、アクセス交 通機関の運貨、時間および乗用車保有 状況、年収などきめ細かな変数が導入 でき、極めて良好な結果を得た（世帯 モデルでも同様に良好な結果を得てい る）。今後、更に新たなデーータ収集 を行うことによりモデルの精䌦化が可 能であると考える。

\section{7 . 結論}

本研究の結諞をまとめると以下のと うりである。

(1) 我国の既存旅客統計調査を対象 とする交通機関、対象とする旅行目的 純流動調査であるか否かなど、今後 の幹線交通政策立案の基磱資料として 必要と考えられる視点から検討を行っ た。その結果满足でるる旅行統計調査 は無く、新たな胭査の必要性が判明し た。
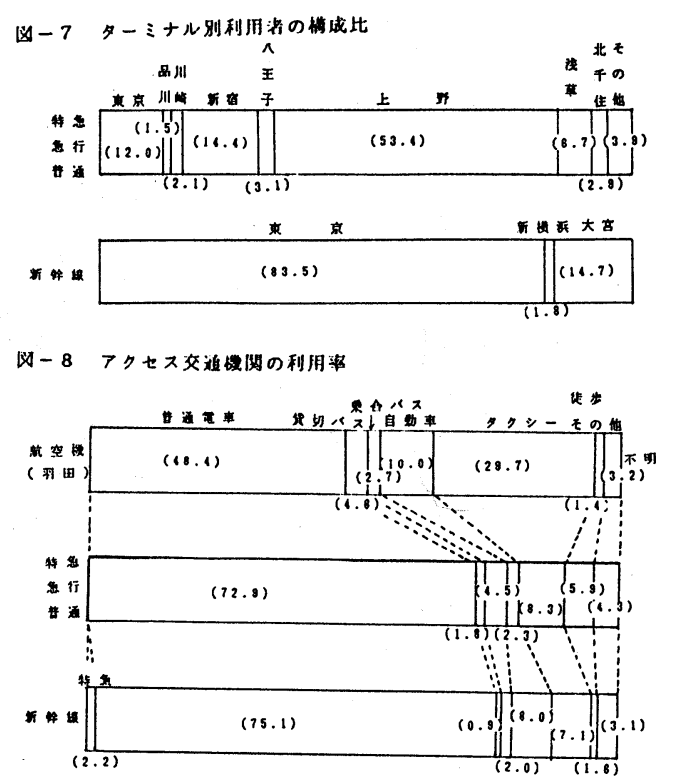

因-9乘用車保有の有繁别交通機闻分担事

(東京)

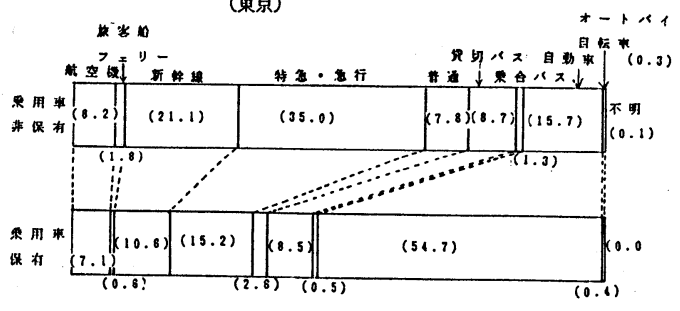

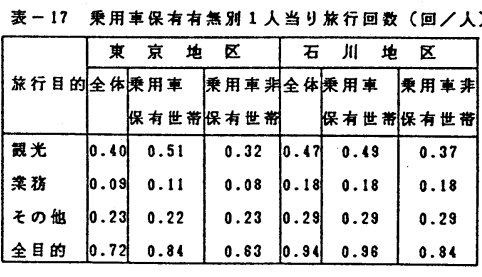

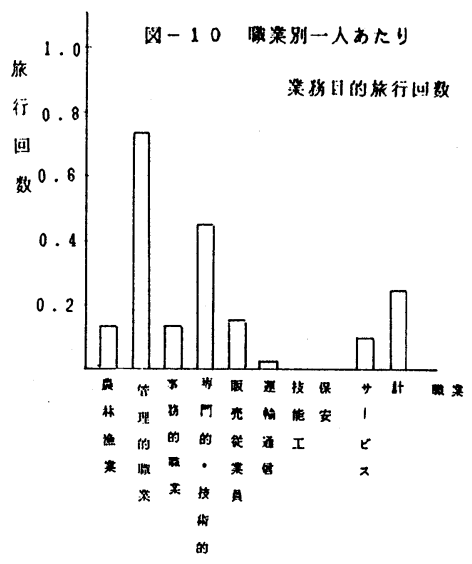

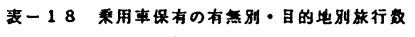

\begin{tabular}{|c|c|c|c|c|c|}
\hline \multirow{3}{*}{ 地 } & \multicolumn{2}{|c|}{ 乘用車保有 } & \multicolumn{2}{|c|}{ 乗用本非保有 } & \multirow{3}{*}{$A<B$} \\
\hline & \multirow{2}{*}{ 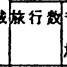 } & \multirow{2}{*}{$\begin{array}{l}\text { 千人当りの } \\
\text { 旅行数: }\end{array}$} & \multirow{2}{*}{ 校行数 } & \multirow{2}{*}{$\begin{array}{l}\text { 千人当りの } \\
\text { 旅行数:B }\end{array}$} & \\
\hline & & & & & \\
\hline 北海道 & 17 & 14 & 29 & 10 & 1.4 \\
\hline 表果北 & 69 & 59 & 56 & 20 & 3.0 \\
\hline 震東北 & 15 & 13 & 14 & 5 & 2.8 \\
\hline 北成東 & $\begin{array}{lll}1 & 7 & 2\end{array}$ & 147 & $\begin{array}{lll}1 & 1 & 2\end{array}$ & 40 & 3.7 \\
\hline 南閏果 & 8 & 7 & $\begin{array}{ll}14 & 4\end{array}$ & 5 & 1.4 \\
\hline 北 陸 & 47 & 40 & 42 & 15 & 2.7 \\
\hline 甲 & $5 \begin{array}{lll}2 & 2 & 0\end{array}$ & 187 & $\begin{array}{lll}1 & 5 & 1\end{array} \mid$ & 54 & 3.5 \\
\hline 東 & $\left|\begin{array}{lll}3 & 1 & 9\end{array}\right|$ & 272 & $\begin{array}{lll}2 & 3 & 0\end{array}$ & 82 & 3.3 \\
\hline 近 鈢 & 17 & 14 & 20 & 7 & 2.0 \\
\hline 板神 & 10 & 9 & 5 & 2 & 1.5 \\
\hline 山 & 0 & 0 & 2 & 1 & 0.0 \\
\hline 山阐 & 0 & 0 & 7 & 2 & 0.0 \\
\hline 四 国 & 0 & 0 & 0 & 0 & 0.0 \\
\hline 北九州 & 0 & 0 & 6 & 2 & 0.0 \\
\hline 南九州 & 7 & 6 & 12 & 4 & 1.5 \\
\hline 沖 & 2 & 2 & 4 & 1 & 2.0 \\
\hline 站 & $\mid \begin{array}{lll}9 & 0 & 3\end{array}$ & & $\begin{array}{lll}7 & 0 & 4\end{array}$ & & \\
\hline
\end{tabular}


（2）幹線旅客の定義を行い、調査対象とすべきトリップを特定した。

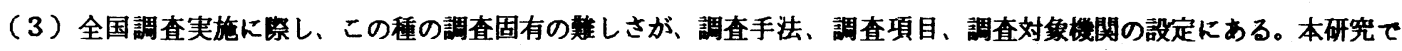
は全国調査に先立ち予璊調査を実施し、この中で調査方法代替案の比較梌討を行い、全国調查の望ましい調㚗方法を提案 した。

（4）予備調査結果を解析し、本調査の実施により新たに判明する旅行目的別の旅行回数、目的地・交通機関の遭択性向 および個人の社会経済属性が旅行特性に及ぼす影篅を分分析し、この種の調㚗が全国幹線交通計画にどのように役立つ かを娭討した。その結果、旅行を真の発着地て捉元、その上で旅行目的別の分析、個人の社会経済属性との関連分析を行 うことが、全国幹線交通計画にとり重要てあるとの結論を得た。

（5）全国調查が実施された場合、調査結果の分析手法として非集計モデルによる分析が考えられる。非集計モデルの全 国幹線交通計画検討への遧用性を検討するために、予借調㚗結果を用いて非集計交通機関選択モデルの構策を試みた。そ の結果、従来の集計タイブモデルの説明变数である運賃、時間以外に、運行頻度、アクセス時間、費用、乗用車保有状况 年収などきめ細かな变数導入ができ、分析手法についても見通しを立てることがてきた。

8 . 謝辞

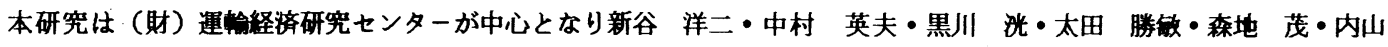
久雄・鹿島 茂・石田 東生の諸先生方の御指導ならびに関係機関の彻力の下に行なったものてあることを記し碀意 を表わします。

参考文献

・運崳省編：運政策寨議会答申ー長期展望に基ずく総合的な交通政策の基本方向、ぎょうせい。

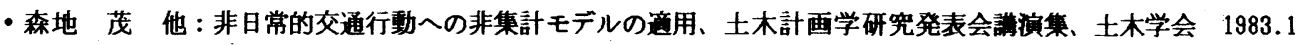

- Marvin L Manhein: Fundamental of Transportation Systens Analysis , The MIT Press

・交通需要予测関与る調㚗研究 1-3、（財）運峆経済研究センター、1978 1980

- 西平 重喜 : 統計調査法、培風館、1980

定式化はロジットモデルで 行った。

\begin{tabular}{|c|c|c|c|c|c|c|c|c|c|c|}
\hline NO & \multicolumn{2}{|c|}{$2-1$} & \multicolumn{2}{|c|}{$2-2$} & \multicolumn{2}{|c|}{$2-3$} & \multicolumn{2}{|l|}{$2-4$} & \multicolumn{2}{|l|}{$2-5$} \\
\hline 站明柿数 & 航 & 新 & 新 & 特 & 新 & 自 & 特 & 自 & 特 & 自 \\
\hline 疑所要時間 & -0.03751 & -0.00162 & -0.00358 & -0.00213 & & & & -0.00185 & & -0.00253 \\
\hline & $(-2.8927)$ & $(-0.1702)$ & $f(-1.6290)$ & $(-1.8322)$ & & & & $|(-2.3033)|$ & & $(-3.8580)$ \\
\hline 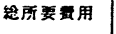 & & & & & -0.00016 & -0.00024 & -0.00017 & -0.00017 & -0.00017 & -0.00017 \\
\hline & & & & & $(-2.0430) \mid$ & $(-1.0846)$ & $(-3.7554)$ & $(-3.7554)$ & $(-3.9082)($ & $(-3.9082)$ \\
\hline 幹線時間 & -0.00461 & -0.02533 & & & & & & & & \\
\hline & $|(-0.3580)|$ & $|(-2.3327)|$ & & & & & & & & \\
\hline 幹缐五用 & -0.00010 & & & & & & & & & \\
\hline & $(-1.1041)$ & & & & & & & & & \\
\hline フクセス時間 & -0.04532 & & & & -0.02597 & & -0.02321 & & -0.01880 & \\
\hline & $|(-1.9383)|$ & & & & $(-2.6337)$ & & $(-3.6885)$ & & $(-3.2084)$ & \\
\hline 通行偊度 & 0.23402 & 0.04275 & 0.03021 & & 0.01332 & & & & & \\
\hline & $(2.3343)$ & $(2.2591)$ & $(3.8185)$ & & ( 1.5114$)$ & & & & & \\
\hline 乗用車保有 & & & & & & 1.74518 & & 1.65541 & & 0.47396 \\
\hline & & & & & & $(5.3174)$ & & $(8.2802)$ & & ( 2.8231) \\
\hline 同行人数 & & $\begin{array}{c}2.79579 \\
2.2308\end{array} \mid$ & & & & & & & & \\
\hline 旅行日摆 & & 2.69299 & & & & -1.36305 & & -1.71855 & & \\
\hline & & $(1.7824)$ & & & & $(-1.9556)$ & & $(-3.7184)$ & & \\
\hline 垔 踏 & & & & & 0.00492 & & & & & \\
\hline 年 取 & & & & & {$\left[\begin{array}{c}2 \\
2.5638\end{array}\right]$} & & & & & \\
\hline 4 W & $\left|\begin{array}{l}-1.39668 \\
(-1.5668)\end{array}\right|$ & & $\left|\begin{array}{c}0.12027 \\
(1.3727)\end{array}\right|$ & & $\left(\begin{array}{c}0.99598 \\
(3.1060)\end{array} \mid\right.$ & & $\left|\begin{array}{c}-0.01679 \\
(-0.0823)\end{array}\right|$ & & & \\
\hline 定数啨 & 6.55124 & & -1.10578 & & -2.40915 & & -0.81663 & & -0.31479 & \\
\hline & $(2.1048)$ & & $(-2.5839)$ & & $(-2.7145)$ & & $(-1.5416)$ & & $(-1.2357)$ & \\
\hline$y^{2}$ & 92 & 2.1 & & 27.8 & & 123.7 & & 138.1 & & 48.2 \\
\hline$\rho$ & & 1.59 & & 0.08 & & 0.28 & & 0.16 & & 0.05 \\
\hline 的中率 (y) & & 18.6 & & 4.5 & & 84.0 & & 76.3 & & 72.2 \\
\hline
\end{tabular}

